\title{
Roofing Materials' Contributions to Storm-Water Runoff Pollution
}

\author{
Shirley E. Clark, P.E. D.WRE, M.ASCE${ }^{1}$; Kelly A. Steele, A.M.ASCE²; Julia Spicher, A.M.ASCE ${ }^{3}$; \\ Christina Y. S. Siü; Melinda M. Lalor ${ }^{5}$; Robert Pitt, P.E. D.WRE, M.ASCE ${ }^{6}$; and \\ Jason T. Kirby, A.M.ASCE ${ }^{7}$
}

\begin{abstract}
Development in sensitive watersheds continues to pose environmental problems for receiving waters. One contributor to this long-term pollution is building and other construction materials. However, the long-term effect of many building materials on the environment has not been quantified due to limited testing of these materials prior to sales and installation. Laboratory "leach" testing of commercially available roofing materials by this research group indicated that the potential for release (primarily nutrients, lighter hydrocarbons, pesticides, and metals) is substantial. Testing of metals' release from aged roofing panels also has shown that the potential for pollutant release still exists after 60 years. The data missing from a complete evaluation of many roofing materials is behavior over the lifespan of the material, including the critical period of initial exposure. The 2 years of runoff data from a pilot-scale testing of these materials indicated substantial concerns regarding zinc from uncoated galvanized metals and copper from treated woods in this early part of the materials' lifespan, plus the potential for long-term nutrient releases in the runoff from several roofing types.
\end{abstract}

DOI: $10.1061 /(A S C E) 0733-9437(2008) 134: 5(638)$

CE Database subject headings: Stormwater management; Water management; Runoff; Water pollution; Roofs; Leaching; Construction materials.

\section{Introduction}

Urban runoff has been identified as a major contributor to the degradation of many urban streams, rivers, and estuaries (Burton and Pitt 2002, which includes an extensive literature review). Using the Microtox acute toxicity testing procedure, Pitt et al. (1995) investigated the toxicity of source-specific urban wet

\footnotetext{
${ }^{1}$ Assistant Professor of Environmental Engineering, School of Science, Engineering and Technology, Penn State Harrisburg, 777 W. Harrisburg Pike TL-105, Middletown, PA 17057 (corresponding author). E-mail: seclark@psu.edu

${ }^{2}$ Engineering Technician, Dawood, Inc., 2020 Good Hope Rd., Enola, PA 17025; formerly, Project Engineer, Navarro and Wright Consulting Engineers, Inc., 151 Reno Ave., New Cumberland, PA 17070. E-mail: ksteele@dawood.cc

${ }^{3}$ Environmental Engineer, Greeley and Hansen, Inc., 1818 Market St., Ste. 3400, Philadelphia, PA 19103-3613. E-mail: jspicher@greeleyhansen.com

${ }^{4}$ Research Scientist, School of Science, Engineering and Technology, Penn State Harrisburg, 777 W. Harrisburg Pike TL-123, Middletown, PA 17057. E-mail: cys106@psu.edu

${ }^{5}$ Associate Dean, School of Engineering, Univ. of Alabama at Birmingham, 1075 13th St. S., Birmingham, AL 35294. E-mail: mlalor@ uab.edu

${ }^{6}$ Cudworth Professor of Urban Water Systems, Dept. of Civil, Construction and Environmental Engineering, Univ. of Alabama, Tuscaloosa, AL 35487-0205. E-mail: rpitt@eng.ua.edu

${ }^{7}$ Assistant Professor, Univ. of Alabama at Birmingham, 1075 13th St. South, Room 140, Birmingham, AL 35294. E-mail: jtkirby@uab.edu

Note. Discussion open until March 1, 2009. Separate discussions must be submitted for individual papers. The manuscript for this paper was submitted for review and possible publication on June 28, 2007; approved on January 28, 2008. This paper is part of the Journal of Irrigation and Drainage Engineering, Vol. 134, No. 5, October 1, 2008. (OASCE, ISSN 0733-9437/2008/5-638-645/\$25.00.
}

weather flows. Roofs, storage areas, streets, and loading docks had the highest frequency of moderately toxic and highly toxic runoff samples. Runoff from roofs and paved surfaces had the greatest organic toxicant detection frequencies and the highest levels of detected metals. Boller (1997) found roof runoff to contain not only heavy metals, but polycyclic aromatic hydrocarbons (PAHs) and organic halogens as well. In addition to the well known component materials in roofing and pavements, seemingly unrelated compounds have been added to improve performance and durability, and these compounds could be the source of many pollutants detected in the runoff.

Based on a review of the literature, other building materials of concern included concrete, paints, and exposed wood/pressure treated wood. A summary of the literature on concrete and asphalt paving can be found in Clark et al. (2002). For paint, the concerns reported were lead and other metals incorporated into the paint itself (Davis and Burns 1999). In New Zealand, limits were placed on the heavy metal content of paints applied to metal construction materials, such as roofs, as an environmental barrier (Kingette Mitchell Ltd. and Diffuse Sources Ltd. 2003). This use of paint as an environmental barrier was, for example, a practice that occurred on a site in the western United States to reduce the zinc release from galvanized metal roofing.

A summary of the literature on roofing (both surface covers and materials used as subbases such as treated wood) is presented in Table 1. The older field studies in the table inferred the differences in roofing's pollutant contributions by analyzing runoff from nearby roofs made from different materials, using small areas where atmospheric contributions could be assumed to be similar. Newer studies directly or indirectly measured atmospheric contributions in order to isolate the materials' contributions. In addition to the research projects that reported runoff concentrations, others investigated the effects of these materials 
Table 1. Roof Runoff Analysis-Literature Summary

\begin{tabular}{|c|c|c|c|c|c|c|c|c|c|c|}
\hline Roof type & Location & $\begin{array}{c}\text { Analytes } \\
\mathrm{Cu} \\
(\mu \mathrm{g} / \mathrm{L})\end{array}$ & $\begin{array}{c}\mathrm{Zn} \\
(\mu \mathrm{g} / \mathrm{L})\end{array}$ & $\begin{array}{c}\mathrm{Pb} \\
(\mu \mathrm{g} / \mathrm{L})\end{array}$ & $\begin{array}{c}\mathrm{Cd} \\
(\mu \mathrm{g} / \mathrm{L})\end{array}$ & $\begin{array}{c}\text { As } \\
(\mu \mathrm{g} / \mathrm{L})\end{array}$ & $\mathrm{pH}$ & $\begin{array}{c}\mathrm{NH}_{4}^{+} \\
(\mathrm{mg} / \mathrm{L})\end{array}$ & $\begin{array}{c}\mathrm{NO}_{3}^{-} \\
(\mathrm{mg} / \mathrm{L})\end{array}$ & Reference \\
\hline Polyester & Duebendorf, Switzerland & 6,817 & 2,076 & 510 & 3.1 & & & & & Boller (1997) \\
\hline Tile & & 1,905 & 360 & 172 & 2.1 & & & & & \\
\hline Flat gravel & & 140 & 36 & 22 & 0.2 & & & & & \\
\hline Plywood w/ roof paper/tar & Washington & $166^{\mathrm{T}} / 128^{\mathrm{D}}$ & $877^{\mathrm{T}} / 909^{\mathrm{D}}$ & $11^{\mathrm{T}} /<5^{\mathrm{D}}$ & & & 4.3 & & & Good (1993) \\
\hline Rusty galv. metal & & & & & & & 5.9 & & & \\
\hline & & & & & & & 4.8 & & & \\
\hline Old metal w/Al paint & & $20^{\mathrm{T}} / 2^{\mathrm{D}}$ & $12,200^{\mathrm{T}} / 11,900^{\mathrm{D}}$ & $302^{\mathrm{T}} / 35^{\mathrm{D}}$ & & & 4.1 & & & \\
\hline Flat tar surface w/fibrous reflective $\mathrm{Al}$ paint & & $11^{\mathrm{T}} / 7^{\mathrm{D}}$ & $1,980^{\mathrm{T}} / 1,610^{\mathrm{D}}$ & $10^{\mathrm{T}} /<5^{\mathrm{D}}$ & & & 5.9 & & & \\
\hline New anodized $\mathrm{Al}$ & & $25^{\mathrm{T}} / 14^{\mathrm{D}}$ & $297^{\mathrm{T}} / 257^{\mathrm{D}}$ & $10^{\mathrm{T}} / 5^{\mathrm{D}}$ & & & & & & \\
\hline & & $16^{\mathrm{T}} / 7^{\mathrm{D}}$ & $101^{\mathrm{T}} / 82^{\mathrm{D}}$ & $15^{\mathrm{T}} /<5^{\mathrm{D}}$ & & & & & & \\
\hline Zinc-galv. Fe & Dunedin City, New Zealand & $560 \mu \mathrm{g} / \mathrm{g}$ & $5,901 \mu \mathrm{g} / \mathrm{g}$ & $670 \mu \mathrm{g} / \mathrm{g}$ & & & & & & Brown and Peake (2006) \\
\hline $\mathrm{Fe}-\mathrm{Zn}$ sheets & Ile-Ife, Nigeria & & & & & & 6.77 & 0.06 & 1.52 & Adeniyi and Olabanji (2005) \\
\hline Concrete slate tiles & & & & & & & 7.45 & 0.05 & 3.34 & \\
\hline Asbestos cement sheets & & & & & & & 7.09 & 0.06 & 2.26 & \\
\hline Aluminum sheets & & & & & & & 6.68 & 0.05 & 6.18 & \\
\hline $\mathrm{Cu}$ panels & Munich, Germany & $200-11,100$ & & & & & $6.7-7.0$ & & & Athanasiadis et al. (2006) \\
\hline Galvanized metals (primarily Galvalume) & Seattle, Wash. & $10-1,400$ & $420-14,700$ & ND & & & & & & Tobiason et al. (2004) \\
\hline CCA wood & Florida & & & & & $1,200-1,800$ & & & & Khan et al. (2006) \\
\hline Untreated wood & & & & & & $2-3$ & & & & \\
\hline
\end{tabular}

\footnotetext{
Note: Fraction of metal: $\mathrm{D}=$ dissolved, $\mathrm{T}=$ total; $\mathrm{ND}=$ not detected.
} 
on receiving waters and biota. Bailey et al. (1999) investigated the toxicity to juvenile rainbow trout of runoff from British Columbia sawmills and found that much of the toxicity may have been a result of divalent cations, in particular, zinc from galvanized roofs. Other sources of toxicity included tannins and lignins from the woods. Lebow et al. (1999) tested chromated-copperarsenate (CCA) treated wood in seawater and deionized water and found that the steady-state release rate of copper was much greater in seawater than in deionized water (vice versa for arsenic). Seawater testing may be indicative of material behavior when exposed to salt-laced rainwater in the winter.

Stormwater runoff in a ditch water near pentachlorophenol (PCP) treated utility poles had chlorophenol concentrations 1.8 times the $96-\mathrm{h} \mathrm{LC}_{50}$ (lethal concentration for $50 \%$ of the salmonid test organisms) (Stranks 1976). As these studies showed, preservative release during storms from $\mathrm{CCA}$ and other preserved woods was sufficiently high to be implicated in these toxicity studies. These materials, therefore, have to be of concern in the environment since they are used as subbase for roofing, as eaves or, in the case of cedar, as a roofing material itself.

Wallinder et al. (2007) and Van Assche et al. (2003) modeled worldwide copper and zinc runoff rates, respectively, based on runoff rates and concentrations reported in the literature, in addition to laboratory testing on degradation. These results, in combination with the runoff concentrations reported in Table 1, indicated that roofing has the potential to be a significant pollutant source in the urban environment, where roofing covers a substantial fraction of the landscape.

What cannot be determined from the prior roofing runoff studies and the Table 1 results is the contribution to toxicity and runoff pollutant concentrations from the various roofing materials themselves versus contributions from atmospheric deposition. The literature very strongly suggests that these materials contribute to increased runoff pollutant concentrations. This is evident especially when nearby roofs of different compositions produce vastly different runoff concentrations. To address the concerns about pollutant release in the field from common construction materials, laboratory "leaching" studies (Pitt et al. 1999; Clark 2000) were performed. The results indicated that the potential existed for many construction materials to release pollutants into the environment. Concerns about the environmental impacts of roofing led to the development of newer materials. However, these newer materials do not have readily available results showing both their short-term and long-term pollutant contributions to urban runoff.

This ongoing research project examined a variety of roofing materials (including subbase materials such as treated and untreated woods and roofing felts, which may be exposed both during roof installation and after damage to the roof) to determine their long-term pollutant release after typical installation and exposure to the weather. The goal was to develop a better understanding of how aging and exposure processes impacted the temporal release of pollutants to runoff which, eventually, should translate into a model of pollutant release over the material's life cycle.

\section{Methodology}

This research consisted of two parts: (1) a laboratory leaching study of test coupons (including a simulated runoff event on aged roofing sections, described below); and (2) a 2-year (to date), pilot-scale field study in Pennsylvania. The project focused on roofing and subbase materials commonly used in the roofing industry. The categories of materials investigated during the laboratory-scale survey included the following:

1. Roofing materials (galvanized metal, asphalt/tar shingles, cedar shingles, plastic/vinyl/fiberglass roofing panels, fake slate roofing, and roofing sealers); and

2. Woods [one $(2 \times 4)$ treated with CCA, another $(2 \times 4)$ with an alternative waterproofing compound (modified copper combination), and one untreated wood].

The materials, with two exceptions, were purchased from Lowes Home Improvement Stores in Birmingham, Ala., for the laboratory studies, and in Harrisburg, Pa., for the field studies. The aged metal roofing panels ( $\sim 60$ years old), used in laboratory studies only, were obtained from a barn in Lancaster County, Pa. One panel was on the roof for the entire time and was rusted. The second panel was stored in the barn as a replacement and still had its paint intact. Besides the paint, which likely contained lead, it was unknown whether the panels were subjected to other coating treatments like zinc oxide. The appearance of the panels was similar to galvanized metal. The results from testing these older materials guided the experimental design for the field studies, particularly in terms of monitoring program length.

\section{Laboratory “Leaching” Studies}

The laboratory tests were performed in 2002 using a modified toxicity characteristic leaching procedure (TCLP) test. This test simulated the exposure of a material or waste to acidic environmental conditions. The two modifications to the USEPAprescribed test were the weight of material (approximately 100-200 g) and the length of exposure [ $48 \mathrm{~h}$ for these tests, using Leachant Solution I-the more aggressive, lower $\mathrm{pH}$ leachant. The $\mathrm{pH}$ of Leachant 1 was approximately $0.5 \mathrm{pH}$ units lower than the acidic rainwater measured at the Penn State Harrisburg (PSH) site]. The resulting leachate for each material (triplicate samples for each material) was analyzed for the following constituents: $\mathrm{pH}$, conductivity, chemical oxygen demand (COD), semivolatile organics, pesticides, heavy metals, major cations, and nutrients. The analytical methodologies were described in Clark et al. (2005) and conformed to methods outlined by EPA or Standard Methods (APHA 1995). The aged roofing panels were analyzed in 2004 using the "leaching" protocols described above, as well as being subjected to a synthetic rainfall applied with a spray bottle over the surface of the material. The formula for the simulated rainwater was from Davis and Burns (1999). The runoff and the original rainwater were analyzed using EPA Method 200.9, with the rainwater concentrations subtracted from the runoff results to obtain the contributions from the materials themselves. For these panels, heavy metals were the only pollutants of interest.

\section{Pilot-Scale Field Testing}

Two sites in the eastern United States were selected for the field tests based on climatic differences: the southern site was at the University of Alabama-Birmingham (UAB), while the midAtlantic site was at PSH. These two sites occur in two EPA rainfall zones (PSH: Zone 1; UAB: Zone 3) and two different rainfall $\mathrm{pH}$ zones (from USGS data, PSH: 4.3-4.5; UAB: >4.8). The roofing materials (whole panels: $1.22 \mathrm{~m} \times 2.44 \mathrm{~m}$, shingles attached in sheet rows as prescribed by the manufacturer) were attached to A frames, with slopes similar to those used in residential pitched roofs (Fig. 1 shows the test setup at PSH). Construction was completed and testing began at PSH in the summer of 


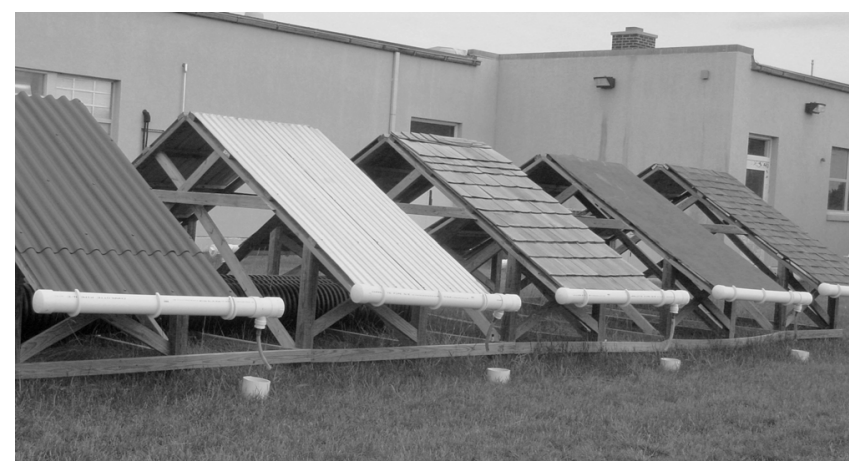

Fig. 1. Roofing setup at PSH field site

2005. At UAB, roofing panels and frames were reconstructed in the spring of 2007 as a result of prior hurricane damage. The test panels were placed on each campus in areas with no overhead canopy to obstruct rainfall onto the panels. Installation techniques and fasteners, including spacing of fasteners, matched those used by roofers to the maximum extent practicable. The panels were left covered until just before the first monitored rain event. The field results portion of this paper focused on the PSH site data since the UAB evaluation recently was restarted. For the PSH site, samples were collected for every storm for the first 2 months, with periodic sampling thereafter.

The field testing evaluated the following materials (manufacturer information provided where available from the store):

- Plexiglass (as a control to quantify and background subtract atmospheric deposition);

- Plytanium plywood [untreated and pressure-treated (CCA)];

- Severe-weather pressure treated/water sealed planks;

- Cedar shakes;

- Roofing felt/tar paper-30 lb. (United Roofing Mfg.);

- Asphalt fiberglass shingles (Supreme Owens Corning 3-tab [25-year limited warranty] treated for 10-year algae resistance);

- Rubberized roofing material (similar to the layer on a built-up roof);

- Galvanized aluminum, corrugated;

- 55\% aluminum-zinc alloy coated steel (Galvalume)prepainted;

- Asphalt impregnated organic fiber panel (Ondura 2002), corrugated; and

- Polyvinyl chloride panel, corrugated.

Analytes included $\mathrm{pH}$ (including periodic direct measurement of rainfall by $\mathrm{pH}$ meter in beaker of rainfall collected during a storm; the $\mathrm{pH}$ was measured as soon as sufficient rainwater was collected to submerge the probe tip), specific conductance, COD, nutrients, and heavy metals. These parameters were analyzed using the methods described in Clark et al. (2005), except for metals which were analyzed, after nitric-acid digestion, by graphite furnace/atomic absorption spectrophotometry (GFAA) (Perkin-Elmer Zeeman 5100, Perkin-Elmer) in accordance with EPA Method 200.9.

\section{Results and Discussion}

\section{Laboratory "Leaching” and Simulated Runoff Tests}

The results from the modified TCLP test were used to indicate if a pollutant "existed" in the material, and whether, over time, it might be released to the environment. The organic data indicated very little potential contributions of specific semivolatile organics (highest leachate concentration $=315 \mu \mathrm{g} / \mathrm{L}$ of bis(2-ethylhexyl) phthalate, a common plasticizer, in roofing felt). The lack of elevated bis(2-ethylhexyl) phthalate concentrations in other samples indicated that this result likely was not due to environmental contamination of the samples, but to dissolution of the felt paper in the leachant solution.

For the nutrients and metals, all samples were run in triplicate and the results averaged after background subtraction of the initial leachant solution concentration. These results are shown in Table 2. Even though each subsample was cut from the same intact panel of material, the heterogeneity of the materials themselves was reflected in the high variability seen in the data (in many cases, coefficients of variation were 2.0 or greater). Therefore, these comparisons were not made based on absolute values of the median concentration, but on general observations made from the data. The results from the nutrient testing showed release of nitrate and phosphate to the leachate, especially of phosphate from the galvanized metal. A review of hot-dip and cold galvanizing process information available online from several manufacturers indicated that phosphorus may be an ingredient in some binders and some wash solutions. The metals' results also showed that significant potential exists for metals to be leached from these materials as they degrade. This was expected for certain materials, such as the galvanized metal, the shingles, the treated wood, and several sealers that listed one or more metals as ingredients since certain metals were added as a protective coating or impregnated in the exposed surface of the material. Table 2 results highlight the reservoir of pollutants potentially available for release during storm events.

The leach testing indicated the "size" of the pollutant reservoir in new materials, but did not address the potential of aged roofing to release pollutants. Two aged $(60+$ year old), painted metal roofing panels were evaluated using both leach testing and simulated rainfall. One panel was exposed to the atmosphere since installation and was rusted across approximately $75 \%$ of the surface area, while the other was an intact replacement panel. The panels were subjected to the following tests: (1) a dissolution test in which an approximate $100 \mathrm{~g}$ piece of the panel was submerged in concentrated nitric acid; (2) a leaching test (approximately $100 \mathrm{~g}$ ) similar to the previously discussed laboratory work; and (3) a simulated rain exposure test. While these exact material formulations currently may not be available, these results were used to develop the field testing plan and to determine if an "end date" may exist in the pollutant release.

The lead results showed that releases from the aged panels were between 0.01 and $1 \mathrm{~g} / \mathrm{kg}$ for the dissolution and leaching tests (not shown). Prior to testing, it was thought that lead would result mostly from what was likely lead paint. However, the testing on the bare metal (the nonrusted portion) showed lead concentrations equivalent to that of the painted metal, indicating two potential causes: (1) lead was a component of the metal roofing panel itself; or (2) lead was deposited on the bare metal surface and "contaminated" the bare roofing. Unlike copper and iron, lead also was released from the material during "rain."

The results for zinc are shown in Fig. 2 as a comparison between the results in the "leach" tests described above and simulated rain. The 2002 leach test results were designated as "pristine" panels since they were purchased less than 1 month before testing. The results indicated that substantial quantities were released from the material during both the dissolution and leaching tests. It also was apparent that "raining" on the material 
Table 2. Laboratory Leaching of Building Materials ${ }^{\mathrm{a}}$

\begin{tabular}{|c|c|c|c|c|c|c|c|c|}
\hline Material & $\begin{array}{c}\mathrm{PO}_{4} \\
(\mathrm{mg} / \mathrm{kg})\end{array}$ & $\begin{array}{c}\mathrm{NO}_{3} \\
(\mathrm{mg} / \mathrm{kg})\end{array}$ & $\begin{array}{l}\mathrm{NH}_{3}-\mathrm{N} \\
(\mathrm{mg} / \mathrm{kg})\end{array}$ & $\begin{array}{c}\mathrm{COD} \\
(\mathrm{mg} / \mathrm{kg})\end{array}$ & $\underset{(\mathrm{mg} / \mathrm{kg})}{\mathrm{CU}}$ & $\begin{array}{c}\mathrm{Pb} \\
(\mathrm{mg} / \mathrm{kg})\end{array}$ & $\begin{array}{c}\mathrm{Zn} \\
(\mathrm{mg} / \mathrm{kg})\end{array}$ & $\begin{array}{c}\mathrm{Fe} \\
(\mathrm{mg} / \mathrm{kg})\end{array}$ \\
\hline Asphalt/tar shingles & $29.4(0.5)$ & $1.52(0.4)$ & $0.83(0.8)$ & $2,698(0.4)$ & $0.66(1.1)$ & $0.34(0.5)$ & $1.22(0.3)$ & $46.7(0.2)$ \\
\hline Roofing felt & $44.6(0.245)$ & $4.2(1.7)$ & $108(0.9)$ & $26,367(0.9)$ & $0.026(2.4)$ & $0.11(0.2)$ & $0(0.05)$ & $1.87(0.4)$ \\
\hline Ondura red vinyl roofing & $0(\mathrm{na})^{\mathrm{b}}$ & $2.44(2.4)$ & $1.44(0.4)$ & $13,161(0.6)$ & $0(\mathrm{na})^{\mathrm{b}}$ & $0(\mathrm{na})^{\mathrm{b}}$ & $0(\mathrm{na})^{\mathrm{b}}$ & $0(\mathrm{na})^{\mathrm{b}}$ \\
\hline Fiberglass roofing & $0.86(1.7)$ & $0(\mathrm{na})^{\mathrm{b}}$ & $0(\mathrm{na})^{\mathrm{b}}$ & $0(0.9)$ & $0.017(2.0)$ & $0.005(4.2)$ & $0.53(0.9)$ & $0(\mathrm{na})^{\mathrm{b}}$ \\
\hline White plastic roofing & $0(\mathrm{na})^{\mathrm{b}}$ & $0.99(1.7)$ & $0(\mathrm{na})^{\mathrm{b}}$ & $6,842(0.5)$ & $0.076(0.4)$ & $0(\mathrm{na})^{\mathrm{b}}$ & $1.42(0.1)$ & $2(0.7)$ \\
\hline Cedar roofing shingles & $1.23(1.0)$ & $0(\text { na })^{b}$ & $0(0.7)$ & $18,852(0.6)$ & $0.033(1.1)$ & $0.11(0.4)$ & $0.64(1.2)$ & $1.64(0.3)$ \\
\hline Galvanized metal roofing & $53.8(1.2)$ & $58.4(0.3)$ & $12.1(0.2)$ & $20,471(0.1)$ & $0.44(0.5)$ & $0.16(1.2)$ & $16,500(0.03)$ & $9,400(0.4)$ \\
\hline Galvanized metal roofing (replicate) & $30.8(1.5)$ & $\mathrm{na}^{\mathrm{b}}(\mathrm{na})^{\mathrm{b}}$ & $1.14(0.7)$ & $0(0.3)$ & $0(0.09)$ & $1.61(0 . .3)$ & $11,900(0.01)$ & $3,300(0.4)$ \\
\hline Waterproofed wood & $0(\mathrm{na})^{\mathrm{b}}$ & $9.12(0.2)$ & $0(\mathrm{na})^{\mathrm{b}}$ & $0(0.5)$ & $161(0.2)$ & $0.29(0.3)$ & $3.72(0.8)$ & $3.22(3.1)$ \\
\hline Pressure treated wood & $62.2(0.06)$ & $6.47(0.2)$ & $0.38(0.8)$ & $53,002(0.2)$ & $191(0.05)$ & $0(\mathrm{na})^{\mathrm{b}}$ & $1.35(0.02)$ & $2.69(0.5)$ \\
\hline Fake slate roofing shingle & $0.07(1.7)$ & $2.71(0.4)$ & $0(\mathrm{na})^{\mathrm{b}}$ & $0(0.3)$ & $0.2(0.1)$ & $0.42(0.07)$ & $1.81(0.3)$ & $20.1(1.1)$ \\
\hline Leak stopper rubberized roof patch & $0.05(1.7)$ & $9.43(0.5)$ & $0(\mathrm{na})^{\mathrm{b}}$ & $726(15.4)$ & $0.13(0.5)$ & $3.78(0.8)$ & $2.61(0.9)$ & $2.25(1.0)$ \\
\hline Kool seal acrylic patching cement & $21.6(1.7)$ & $0(\mathrm{na})^{\mathrm{b}}$ & $0(\mathrm{na})^{\mathrm{b}}$ & $2,297(1.2)$ & $0.15(1.4)$ & $0.65(0.9)$ & $2.94(1.5)$ & $229(0.9)$ \\
\hline Gardner Wet-R-Dri roofing patch & $203(0.6)$ & $0(\mathrm{na})^{\mathrm{b}}$ & $0(\mathrm{na})^{\mathrm{b}}$ & $0(2.7)$ & $0(11.1)$ & $0.094(1.3)$ & $0(\mathrm{na})^{\mathrm{b}}$ & $1.39(5.1)$ \\
\hline Silver dollar aluminum roof coating & $0(\text { na })^{b}$ & $\mathrm{na}^{\mathrm{b}}(\mathrm{na})^{\mathrm{b}}$ & $n a^{b}(n a)^{b}$ & $21,520(1.1)$ & $1.14(1.0)$ & $0.3(6.1)$ & $0(\mathrm{na})^{\mathrm{b}}$ & $151(0.5)$ \\
\hline
\end{tabular}

${ }^{\mathrm{a}}$ Table value equals average concentration [coefficient of variation (std. dev./avg.) in parenthesis].

${ }^{b}$ na $=$ not available. Coefficient of variation cannot be calculated because none of the triplicate samples was indistinguishable from the background (material contribution was zero).

caused zinc to be released to the environment, although the magnitude of the release was $>2 \log$ less than the release from dissolution and leaching. While these results were not comparable directly since they were not from the same manufacturer and batch, they were indicative of the zinc reservoir that may be available for release into the environment under the right conditions in the order of several grams per kilogram of roofing panel. Comparatively, the lead, copper, and cadmium releases were 2-4 orders of magnitude less than zinc's releases.

\section{Pilot-Scale Field Tests}

The laboratory testing showed that these materials had a reservoir of pollutants that could be released if conditions were right. However, in order to perform these tests, the materials had to be cut to fit the test vessels. This cutting potentially exposed sublayers that would not be exposed during the material's normal life. The concern was that the cuts, in the aggressive environment of the testing, were the source of the pollutants and that the results would not be easily translatable to the field. Since both the PSH and UAB sites were in areas of the United States with acid rain, these sites were considered ideal for studying the long-term behavior of intact panels (installed according to manufacturer instructions). Because of the destruction of the UAB test site during a hurricane and its recent rebuilding, this paper focused on the PSH results.

Approximately 2 years of field monitoring occurred at PSH. The results are shown in Figs. 3-6 for four pollutants of interest: nitrate, reactive phosphorus, copper, and zinc, respectively. These results have been background corrected using the concentrations from the plexiglass control panel. Results were not included in this paper for $\mathrm{pH}$, specific conductance, total nitrogen, total phosphorus, ammonia, and lead for every material. Since this testing occurred well after lead phaseout from gasoline, lead concentrations from the materials, after background correction, were approximately $0 \mathrm{mg} / \mathrm{L}$. pH for all materials were below neutral, with runoff pHs measuring between 5 and 6.5 for all materials except the cedar shakes (consistently approximately 4.5-5).
For the nutrients and copper graphs, only the results from the treated woods and cedar shakes were incorporated. For zinc, only the galvanized metal and aluminum-zinc alloy coated steel were plotted. These materials were selected for each of these graphs because of the nature of the material—woods composed of nutrients in cells, and copper used as a preservative. Galvanized metal and the alloy coated steel both advertised zinc in the product. In addition, the daily rainfall, as reported by the National Weather Service for the Harrisburg International Airport, was included as a hyetograph on each figure. The airport monitoring location is across Pennsylvania State Route 230 from the test site (within $0.5 \mathrm{~km}$ of the test site).

To confirm that the site was subjected to acid rain, periodic monitoring of rainfall $\mathrm{pH}$ was conducted. The rainfall $\mathrm{pH}$ varied

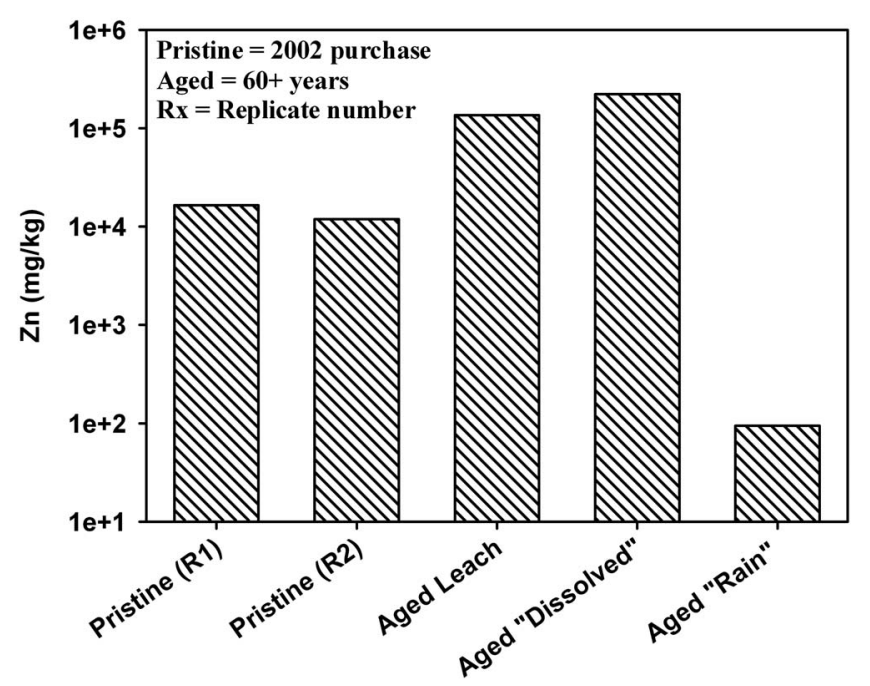

Fig. 2. Zinc in galvanized metals-comparison of new and aged materials 


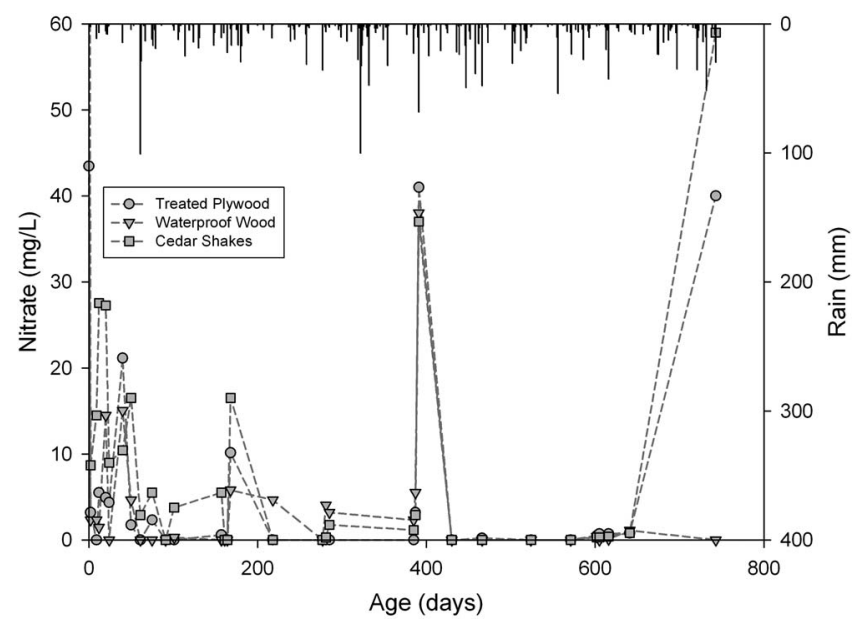

Fig. 3. Nitrate runoff concentrations for wood products

between 3.7 and 6.0, depending on the portion of the storm measured. In addition, the panels were inspected periodically for visible degradation.

The field results showed that nutrient concentrations were elevated early in the materials' lives (Fig. 3 for nitrate as nitrogen, and Fig. 4 for reactive phosphorus as phosphate). Figs. 3 and 4 focused on the wood-based materials only. The woods typically had higher concentrations than the metal-based or vinyl-type roofing for these pollutants. The metal, rubber, and vinyl concentrations (not shown) were closer to background levels with periodic spikes in the runoff (rubberized roofing reactive phosphorus spike of $32 \mathrm{mg} / \mathrm{L}$ at approximately Day 60; galvanized aluminum nitrate spike of $35 \mathrm{mg} / \mathrm{L}$ at Day 50). Similar trends were seen for ammonia, total nitrogen, and total phosphorus. In general, the highest concentrations of these nutrients were found in the runoff from the wood products, and in the case of the nitrate, the untreated wood. This was not surprising since the untreated wood was the first wood product to show visible degradation (a split in the wood), exposing the underlayers to the atmosphere. In addition, since these were wood products, the degradation of cells and the release of nutrients from the cell mass would be anticipated. Because these periodic spikes occurred throughout the 2-year observation period, including winter, and the control data were subtracted from the results before data

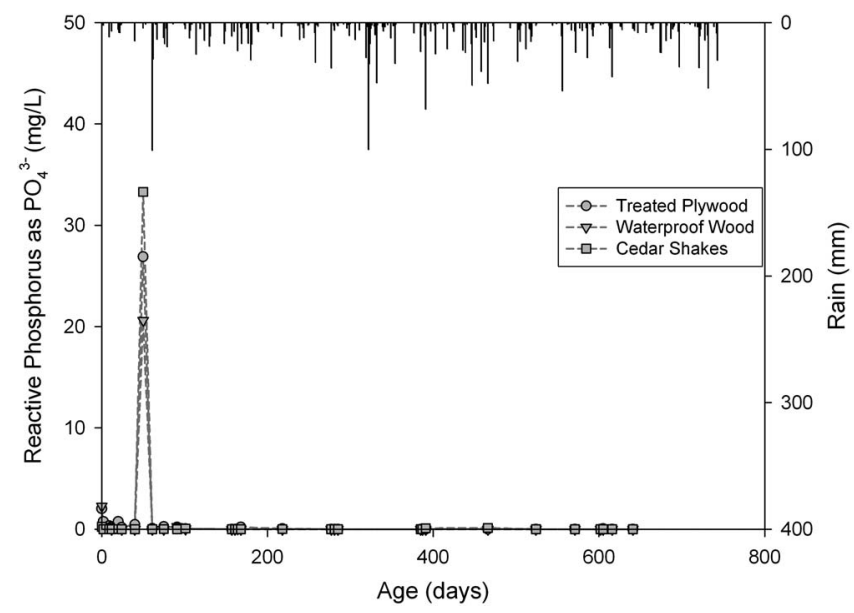

Fig. 4. Reactive phosphorus runoff concentrations for wood products

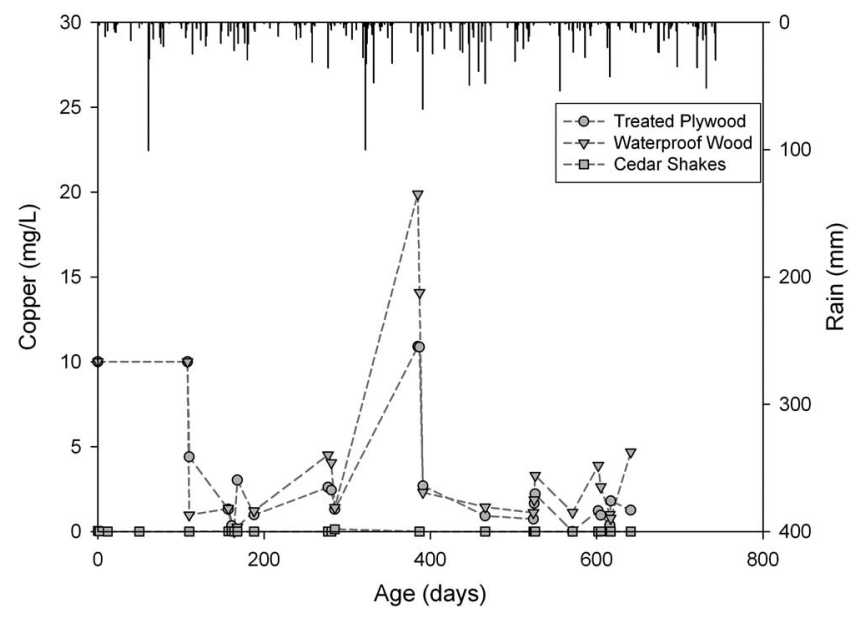

Fig. 5. Copper runoff concentrations for wood products (Note: all values above $5 \mathrm{mg} / \mathrm{L}$ are estimated concentrations because substantial dilution of the sample was needed to be within range of the analytical method)

analysis. These spikes were not believed to be due to wash-on/ blow-on of fertilizer or grass cuttings, but instead, resulted from the materials themselves. In addition, several of these spikes could be correlated to additional visible material degradation (i.e., splitting of the wood).

Good (1993) found that dissolved metals' concentrations and toxicity remained high in roof runoff samples, especially from rusty galvanized metal roofs during first flush and several hours after the rain started, indicating metal leaching continued throughout the events. Figs. 5 and 6 highlight the results for copper and zinc. As noted in the caption, many of the earlier samples from the treated woods had copper concentrations that were very high (upper analytical limit $=5 \mathrm{mg} / \mathrm{L}$; concentrations above $5 \mathrm{mg} / \mathrm{L}$ were measured using substantial dilution and are estimates only). Lead and arsenic concentrations were near background levels, indicating minimal concerns. This was contrary to the results seen by Khan et al. (2006), who noted elevated concentrations of arsenic from treated wood decks. For copper, preliminary results showed that releases were substantially higher than expected for many materials. Rubberized roofing had the highest $\mathrm{Cu}$ concen-

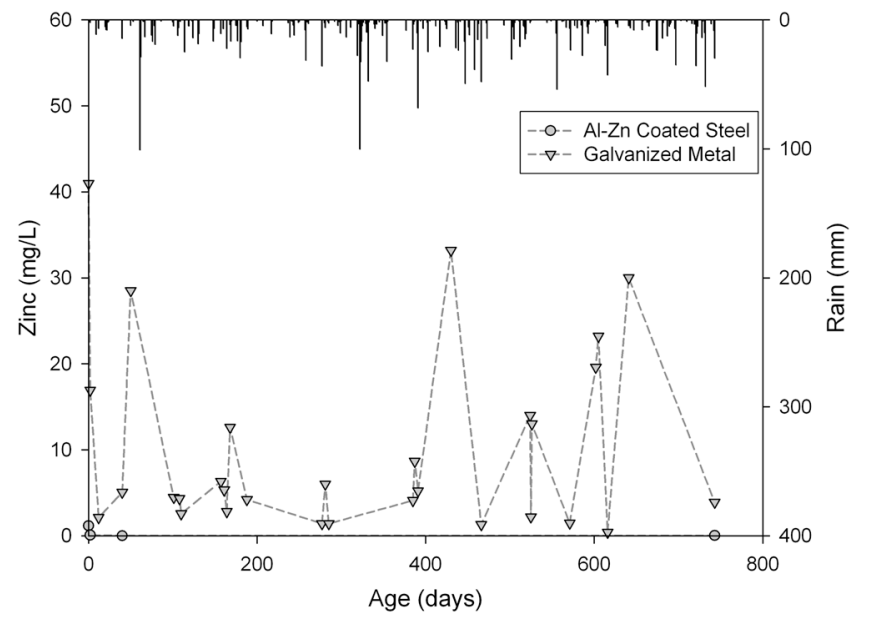

Fig. 6. Zinc runoff concentrations for galvanized metal and aluminum-zinc alloy coated steel 
tration of the metal, rubber, and vinyl materials (data not shown), $<70 \mu \mathrm{g} / \mathrm{L}$ at Day 50. The remaining materials from this group showed concentrations near background levels and less than $20 \mu \mathrm{g} / \mathrm{L}$. Runoff concentrations of copper for the two treated wood panels (Fig. 5) exceeded $5 \mathrm{mg} / \mathrm{L}$ for the first 9 months of exposure. Only after 270 days postinstallation did the copper concentrations from these woods approach the analytical range of the instrumentation. These results indicated that copper continued to be released from these wood products and at levels high enough to exceed the aquatic life criteria and that this release likely was not due to an excess surface coating that would wash off in the first few storms postinstallation.

The literature showed that zinc from traditional unpainted or uncoated hot-dip galvanized steel could be an environmental concern. Fig. 6 compares the zinc runoff concentrations from a traditional galvanized panel and from Galvalume, a prepainted aluminum-zinc alloy coating on steel. The results showed that the zinc runoff concentration was $5-30 \mathrm{mg} / \mathrm{L}$ throughout the first 2 years of monitoring for the traditional galvanized metal panel, while the prepainted aluminum-zinc alloy panel was less than $250 \mu \mathrm{g} / \mathrm{L}$, more than two orders of magnitude less. Whether the reduction in zinc runoff concentration was due to the painting/ coating on the material or due to a different formulation/ application method for the protective coating cannot be determined from these data.

The laboratory-scale research showed that there could be significant potential for pollutants (especially nutrients and metals) to be released from common roofing materials. However, the laboratory activities did not mimic the cyclic wet-dry weathering (including rainfall, ultraviolet radiation, temperature, etc.) to which these materials are exposed over the course of their 10-50 year life span. Therefore, to better predict the pollutant release over a material's installed lifetime, field testing was started in August 2005 and continues to date. The ongoing field tests confirmed several of the results seen in the laboratory. Metals, such as copper and zinc, still were being released from materials well after any short-term protective coatings should have washed off, indicating that measurable quantities of pollutants may continue to be released in an acid rain environment throughout the material's useful life. This contradicts prior assumptions that releases tended to stabilize to negligible levels over a product's lifespan. Given the large quantity of these materials installed in the environment, the overall contribution may be significant and deserves further investigation.

\section{Conclusions}

The laboratory leaching results showed that traditional galvanized metal roofing contributed the greatest concentrations of many of the pollutants of interest-specific conductance, cations, metals (particularly zinc), and nutrients. In addition, the metals' analyses showed that the pressure treated and waterproofed wood contributed substantial copper loads. The potential for nutrient release exists in many of these materials, such as from the galvanized metal (potentially as a result of phosphate washes and binders used in the material's preparation) and wood products due to natural degradation. Tests conducted in the laboratory on the aged roofing panels suggested that this pollutant release may occur for an extended period of time. The laboratory testing results were limited because they were single tests of a material (which had been precut, exposing edges and the underlying structure) and were performed under very aggressive conditions. Their results were used to decide whether further investigation through a longterm field study was warranted. The 2 years of field testing that began in August 2005 documented low-level, long-term releases of many pollutants from these materials.

These results indicated that investigation of the potential environmental impact of roofing should be encouraged prior to the material entering the market. In addition, stormwater modeling and management should not ignore roofing when assessing sources of pollutants. Roofs do not simply collect atmospheric deposition and transport it to the drainage system. They also may, depending on the material's composition and ability to degrade and release pollutants, be a significant source of pollutants in urban runoff. These results, in combination with those generated from the UAB test site, will be used to develop models that account for the environmental and material characteristics that influence the degradation and release patterns seen in this study and others.

\section{Acknowledgments}

The writers would like to acknowledge the contributions of three undergraduate students at UAB - Blaine Collier, Amanda Lowry, and Bridget Shealy, and one graduate and two undergraduate students at PSH-Brad Mikula, Jim Elligson, and Christopher Roenning. In addition, the writers would like to express their appreciation to the following funding sources: Alabama Water Resources Research Institute and the Penn State Harrisburg Graduate Council Faculty Research Grants Committee.

\section{References}

Adeniyi, I. F., and Olabanji, I. O. (2005). "The physicochemical and bacteriological quality of rainwater collected over different roofing materials in Ile-Ife, southwestern Nigeria." Chem. Ecol., 21(3), 149-166.

American Public Health Association (APHA). (1995). Standard methods for the examination of water and wastewater, 19th Ed., American Water Works Association, Water Pollution Control Federation, Washington, D.C.

Athansiadis, K., Helmreich, B., and Wilderer, P. A. (2006). "Infiltration of a copper roof runoff through artificial barriers." Water Sci. Technol., 54(6-7), 281-289.

Bailey, H. C., Elphick, J. R., Potter, A., and Zak, B. (1999). "Zinc toxicity in stormwater runoff from sawmills in British Columbia." Water Res., 33(11), 2721-2725.

Boller, M. (1997). "Tracking heavy metals reveals sustainability deficits of urban drainage systems." Water Sci. Technol., 35(9), 77-87.

Brown, J. N., and Peake, B. M. (2006). "Sources of heavy metals and polycyclic aromatic hydrocarbons in urban stormwater runoff." Sci. Total Environ., 359(1-3), 145-155.

Burton, G. A., Jr., and Pitt, R. (2002). Stormwater effects handbook: A tool box for watershed managers, scientists, and engineers, CRC, Boca Raton, Fla.

Clark, S. E. (2000). "Urban stormwater filtration: Optimization of design parameters and a pilot-scale evaluation." Ph.D. dissertation, Univ. of Alabama at Birmingham, Birmingham, Ala.

Clark, S. E., Lalor, M. M., and Pitt, R. (2005). "Wet-weather pollution from commonly-used building materials." Proc., World Environmental and Water Resources Congress (CD-ROM), ASCE/EWRI, Reston, Va.

Clark, S. E., Pitt, R., and Field, R. (2002). "Wet-weather pollution prevention by product substitution." Proc., United Engineering Conf. on Linking Stormwater BMP Designs and Performance to Receiving 
Water Impacts, ASCE, Reston, Va., 266-283.

Davis, A., and Burns, M. (1999). "Evaluation of lead concentration in runoff from painted structures." Water Res., 33(13), 2949-2958.

Good, J. C. (1993). "Roof runoff as a diffuse source of metals and aquatic toxicity in stormwater." Water Sci. Technol., 28(3-5), 317-321.

Khan, B. I., Solo-Gabriele, H. M., Townsend, T. G., and Cai, Y. (2006). "Release of arsenic to the environment from CCA-treated wood. 1: Leaching and speciation during service." Environ. Sci. Technol., 40, 988-993.

Kingette Mitchell Ltd., and Diffuse Sources Ltd. (2003). A study of roof runoff quality in Auckland, New Zealand: Implications for stormwater management, Takapuna, Auckland, New Zealand.

Lebow, S. T., Foster, D. O., and Lebow, P. K. (1999). "Release of copper, chromium, and arsenic from treated southern pine exposed in seawater and freshwater." For. Prod. J., 49(7), 80-89.

Ondura. (2002). Ondura® has it all over other roofing, Fredericksburg, Va.

Pitt, R., Field, R., Lalor, M., and Brown, M. (1995). "Urban stormwater toxic pollutants: assessment, sources and treatability." Water Environ.
Res., 67(3), 260-275.

Pitt, R., Robertson, B., Barron, P., Ayyoubi, A., and Clark, S. (1999). Stormwater runoff treatment at critical areas: The multichambered treatment train (MCTT), EPA 600/R-99/017, U.S. Environmental Protection Agency, Water Supply and Water Resources Division, National Risk Management Laboratory, Cincinnati.

Stranks, D. W. (1976). "Wood preservatives: Their depletion as fungicides and fate in the environment." Canadian Forest Service Technical Rep. No. 10, Ottawa, Canada.

Tobiason, S. (2004). "Stormwater metals removal by media filtration: Field assessment case study." Proc., Watershed 2004 Conf. Proc., (CD-ROM), Water Environment Federation, Alexandria, Va.

Van Assche, F., Regoli, L., and Cook, M. (2003). "Atmospheric zinc run-off in a general perspective of diffuse zinc emissions to surface waters: Experience of the EU zinc risk assessment." Korrosionsinstitutet Rap. No. 109E, 159-167.

Wallinder, I. O., Bahar, B., Leygraf, C., and Tidblad, J. (2007). "Modelling and mapping of copper runoff for Europe." J. Environ. Monit., 9, 66-73. 